\title{
AN ORIBATID MITE (ARACHNIDA: ACARI) FROM THE OXFORD CLAY (JURASSIC: UPPER CALLOVIAN) OF SOUTH CAVE STATION QUARRY, YORKSHIRE, UK
}

\author{
by PAUL A. SELDEN*, ANNE S. BAKER $\dagger$ and KENNETH J. PHIPPS $\$$ \\ *The Paleontological Institute, University of Kansas, 1475 Jayhawk Boulevard, Lawrence, Kansas 66045, USA, and Department of Palaeontology, the Natural History \\ Museum, Cromwell Road, London SW7 5BD, UK; e-mail: selden@ku.edu \\ $\dagger$ Department of Entomology, the Natural History Museum, Cromwell Road, London SW7 5BD, UK; e-mail: asb@nhm.ac.uk \\ †Department of Geography, University of Hull, Cottingham Road, Kingston upon Hull, Yorkshire HU6 7RX, UK \\ Typescript received 7 February 2007; accepted 4 June 2007
}

\begin{abstract}
A single specimen of a new species of oribatid mite belonging to the genus Jureremus Krivolutsky, in Krivolutsky and Krassilov 1977, previously described from the Upper Jurassic of the Russian Far East, is described as J. phippsi sp. nov. The mite is preserved by iron pyrite replacement, and was recovered by sieving from the Oxford Clay Formation (Jurassic: Upper Callovian) of South Cave, Yorkshire. It is the first record of a pre-Pleistocene mite, and the
\end{abstract}

second species record of the family Cymbaeremaeidae, from the British Isles; also, it is only the third record of Acari from the Jurassic Period. The presence of a terrestrial mite in a sedimentary sequence of open marine origin is noteworthy, and suggestions for its mode of transport to the site of deposition are discussed.

Key words: Cymbaeremaeidae, marine, Mesozoic.
UBIQUitous and abundant in nearly all terrestrial environments today, mites are, however, uncommon in the fossil record. Today's diversity of mites is second only to that of insects. With some 50,000 extant species described, of which nearly one-quarter $(11,500)$ are oribatids, their past diversity is not well reflected in the fossil record because of their rarity as fossils, especially in older strata. Not only are mites commonly overlooked because of their minute size (the majority are much less than $2 \mathrm{~mm}$ ) but also most micropalaeontologists sample marine sediments where mites normally do not occur. Fossil mites are most abundant in Pleistocene and Holocene sites (Elias 1994; Krivolutsky and Druk 1986) and are being used increasingly in Quaternary biostratigraphic and palaeoclimatic studies (e.g. Erickson 1988; Coetzee and Brink 2003; Erickson et al. 2003; Krivolutsky and Sidorchuk 2003). A few are known from other Cenozoic strata, especially ambers: Baltic (Sellnick 1931; Krivolutsky et al. 1990), Dominican Republic (Norton and Poinar 1993), Mexico (Woolley, 1971), and Russia (Krivolutsky and Ryabinin 1976; Zacharda and Krivolutsky 1985). PreCenozoic mites are far fewer in number, with only a handful of specimens known from Cretaceous ambers of the Taimyr Peninsula, Russia (Bulanova-Zachvatkina 1974; Zacharda and Krivolutsky 1985), New Jersey (Klompen and Grimaldi 2001), Canada (Ewing 1937; McAlpine and Martin 1969; Vercammen-Grandjean 1973) and Myanmar (Grimaldi et al. 2002; PAS and ASB, pers. obs.), and the Cretaceous Crato Formation of Brazil (Dunlop 2007). Oribatids are known from the Upper Jurassic of the Far East of Russia (Krivolutsky and Krassilov 1977), and a single oribatid has been described from the Lower Jurassic of Sweden (Sivhed and Wallwork 1978). In Palaeozoic rocks, some undescribed mites have been recovered in acid residues from Devonian and Carboniferous rocks of Germany (Braun 1997) and Carboniferous shale from Lone Star Lake, Kansas (PAS and ASB, pers. obs.). The oldest known undisputed mite fossils come from the Devonian localities of Rhynie, Scotland (Hirst 1923) and Gilboa, New York (Norton et al. 1988; Kethley et al. 1989). Two of those from Gilboa, Devonacarus sellnicki Norton, in Norton et al. 1988 and Protochthonius gilboa Norton, in Norton et al. 1988, are oribatids. A record of an oribatid mite from early Ordovician rocks of Öland, Sweden (Bagnoli et al. 2000; Bernini et al. 2002) remains enigmatic because it is possible that the supposed fossil mite is a Recent contaminant (see Jeram et al. 1990 for discussion of the criteria required to determine this). If proven, however, this would be an exciting find because it would be the oldest known body fossil of a terrestrial animal, preceding the current record (mid-Silurian millipedes: Wilson and Anderson 2004) by more than $50 \mathrm{Ma}$. In addition, trace fossils attributed to mite activity are increasingly being documented (Labandeira et al. 1997; Ash 2000; Kellogg and Taylor 2004). 
With their hard exoskeleton in the adult, oribatids fossilize rather better than other mites and have a relatively good fossil record: see the reviews by Krivolutsky and Druk (1986) and Bernini (1986, 1991), and the compilation in Labandeira et al. (1997, appendix 1). The oribatid mite described here can be assigned to the known Jurassic genus Jureremus Krivolutsky, in Krivolutsky and Krassilov 1977. It is the first record of a pre-Pleistocene fossil mite and the second species record of Cymbaeremaeidae from the British Isles, the third occurrence of Jurassic Acari, and is unusual in coming from the marine sedimentary record.

\section{LOCALITY}

South Cave Station Quarry (National Grid reference SE 920329) is located on the western edge of the Yorkshire
Wolds escarpment, approximately $2 \mathrm{~km} \quad$ (1.25 miles) north-north-west of South Cave village (Text-fig. 1). It lies on the south side of Drewton Dale, a small valley that runs north-east-south-west across the outcrop of Jurassic and Cretaceous strata at the edge of the scarp slope. The construction of the Hull and Barnsley Railway in 1881 produced a cutting at Drewton in which a section through the Kellaways Beds and Oxford Clay was revealed (Keeping and Middlemiss 1883). A pit to the north of the railway line was opened in order to extract the Kellaways Sands (now the Kellaways Sand Member of the Kellaways Formation; Page 1989) and the demand from the metal-casting industry for this fine moulding sand resulted in the expansion of the site. Further sand extraction since the closure of the railway line in 1959 caused the western portion of Drewton Cutting to become part of the main quarry. Therefore, the location

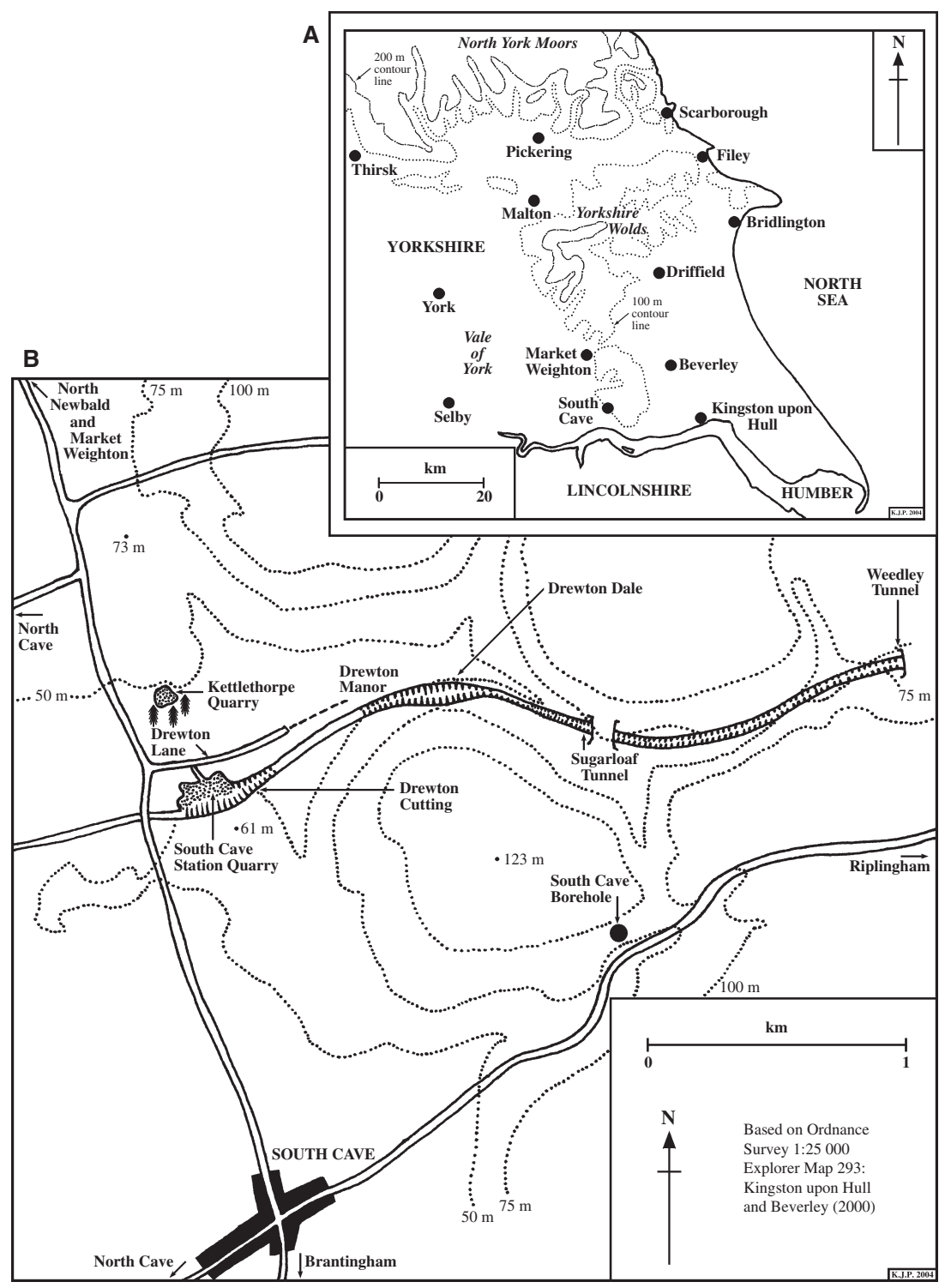

TEXT-FIG. 1. Map showing the location of South Cave Station Quarry (after Phipps 2007). A, regional setting. $B$, South Cave and the surrounding area. Map B is reproduced by kind permission of Ordnance Survey (c) Crown Copyright NC/04/27104. 
from which the specimen came is referred to as South Cave Station Quarry in this paper. The limited outcrop of Oxford Clay at this site occurs on the southern side of the former cutting, at the top of quarry faces that have been created during the extraction of the Kellaways Sand Member.

South Cave Station Quarry has provided material for a number of papers on Jurassic palaeontology, all of which have been concerned with the Kellaways Formation. Ammonites from the Kellaways Rock (Cave Rock Member sensu Page 1989) were used by Arkell (1945) in his examination of the zones of the Upper Jurassic, and the quarry was designated the type locality for the Sigaloceras planicerclus [now Sigaloceras (Catasigaloceras) enodatum] Subzone by Callomon (1955, 1964). Perisphinctid ammonites from this location were featured in Cox's (1988) monograph on English Callovian species. The bivalve fauna was considered by Walker (1972) and the depositional environments of the Kellaways Beds were discussed by Brasier and Brasier (1978). The quarry, which is a Site of Special Scientific Interest (SSSI) owing to its geological features and significant living amphibian populations, appears with the nearby Kettlethorpe Quarry as the 'Drewton Lane Pits' in the recent Geological Conservation Review Series publication on Middle Jurassic stratigraphy (Page and Cox 2002). English Nature (now part of Natural England), the organization with responsibility for SSSIs, has stressed that there should be no indiscriminate hammering of, or collecting from, the exposures at South Cave Station Quarry.

\section{STRATIGRAPHY AND PALAEOECOLOGY}

The main outcrop of the Oxford Clay in England stretches from the Dorset coast to north-east Yorkshire. It ranges in age from latest Early Callovian to Early Oxfordian and a tripartite division has been in use for many years (Lower, Middle and Upper Oxford Clay). Cox et al. (1992) recognized the Oxford Clay as a Formation and the traditional lithostratigraphic subdivisions became the Peterborough, Stewartby and Weymouth members respectively. Strata belonging to this formation are poorly exposed in the South Cave area of Yorkshire and the exact age of the deposits at Station Quarry is uncertain (Neale 1958). The specimen described in this paper was collected from a temporary pit excavated by KJP as part of a detailed examination of the palaeontology and stratigraphy of the Oxford Clay at this site (Phipps 2007). Text-figure 2 shows a composite section through the lower part of the succession based on observations made in three pits. The standard zones and lithostratigraphic terms used in Text-figure 2 have been recognized on the basis of macro- and microfossil evidence collected and interpreted by KJP.

The grey mudstones of the Phaeinum Subzone are similar to the deposits described from a number of sites in the East Midlands by Callomon (1968). Although these mudstones are rich in organic matter, a deep anoxic depositional environment seems unlikely. Depth estimates range between 10 and $50 \mathrm{~m}$ (Martill et al. 1994) and the sea-bed was oxygenated (MacQuaker 1994). However, it is certain that the mite is a terrestrial form and thus allochthonous.

\section{MATERIAL AND METHODS}

The specimen (KJP collection number SCSQOxCl mf 28) was collected from the sieve residue of a $1000 \mathrm{~g}$ sample of Peterborough Member mudstone (Athleta Zone, Phaeinum Subzone) from Pit One at South Cave Station Quarry. The sediment sample was broken into small fragments and then covered with 61 of boiling water to which $150 \mathrm{ml}$ of washing-machine powder had been added. Once disaggregation was complete (2-3 days), wet sieving through 500, 250 and $125 \mu \mathrm{m}$ mesh sieves isolated the macrofossil fragments and microfossils. These were dried at room temperature and examined using a binocular microscope (magnification $\times 40$ ). In Manchester, the specimen was photographed (Text-fig. 3) and drawn first under light microscopy because of the danger of loss during evacuation in scanning electron microscopy (SEM). It was then prepared for SEM by securing on a double-sided sticky carbon pad; this enabled the specimen to be moved between SEM sessions so that it could be viewed from different angles. Being composed of electrically conductive iron pyrite, there was no need for the specimen to be coated for SEM.

The specimen consists of an internal mould of iron pyrite and a cast of the body cuticle, also in pyrite. High magnification SEM shows the cubic nature of the casting pyrite (e.g. Text-figs 4A, 5A, C). Pyrite preservation is common in parts of the Oxford Clay Formation of Yorkshire; details of the factors influencing pyrite formation have been provided by Hudson and Palframan (1969), Hudson (1982), and Fisher and Hudson (1987). That the mite specimen is preserved in iron pyrite typical of the Oxford Clay Formation makes it extremely unlikely that it is a modern contaminant. The specimen is incomplete: the genital plates, most of the prodorsum, gnathosoma and leg articles are missing. In addition, the specimen shows breakage of part of the ventral cuticle. It is possible that this damage occurred during matrix disaggregation and sieving. The dorsal part of the notogaster was lost during scanning electron microscopy (compare the light microscope photograph, Text-fig. 3A, 




TEXT-FIG. 2. Composite section through the lower part of the Oxford Clay Formation at South Cave Station Quarry. Standard zonation based on Callomon (1968), Duff (1978) and Martill and Hudson (1991). The lithostratigraphic terms are those introduced by Page (1989) and Cox et al. (1992). Traditional names are shown in brackets. with the SEM photograph, Text-fig. 4A). Measurements were calculated from the SEM photographs. The specimen is deposited in the Oxford University Museum of Natural History.

Abbreviations. I-IV, leg numbers; a pl, anal plate; ac, acetabulum; ad2, adanal seta; ?an, suspected alveolus of anal seta; b, bothridium; c, anterior collar of notogaster; ep, epimere; fe, femur; $\mathrm{g}$ a, genital aperture; $\mathrm{n}$, notogaster; $\mathrm{p}$, prodorsum; ?p r, putative prodorsal ridge; $\mathrm{p}$ scl, preanal sclerite; $\mathrm{pd}$, pedotectum; tr, trochanter; v pl, ventral plate.

\section{SYSTEMATIC PALAEONTOLOGY}

\section{Subclass ACARI Leach, 1817 \\ Order ORIBATIDA van der Hammen, 1968 Family CYMBAEREMAEIDAE Sellnick, 1928}

Remarks. Krivolutsky (in Krivolutsky and Krassilov 1977) assigned his new genus Jureremus to Cymbaeremaeidae on the basis of the absence of pteromorphs and lamellae, presence of large, separated anal and genital orifices, notogastral lateral margins that extend to the ventral surface, and capitate sensilli. He commented that some (unspecified) features of Jureremus are similar to those of Micreremus Berlese, 1908, now classified in the family Micreremidae Grandjean, 1954. However, no known Micreremus, or other micreremid, species has such closely positioned genital and anal apertures as occurs in J. foveolatus and the new fossil species. The gap in micreremids is equivalent to at least the length of the genital aperture (deduced from Balogh and Balogh 1998) as opposed to at most about one-third of its length in Jureremus. The familial placement was maintained by Krivolutsky in subsequent papers (Krivolutsky and Druk 1986; Krivolutsky et al. 1990).

The condition of the Jureremus fossil specimens prevents the examination of the majority of structures mentioned in the most recent diagnosis proposed for Cymbaeremaeidae (Behan-Pelletier 1988). Of those that can be observed, the presence of pedotecta I and II and absence of pteromorphs in adults are diagnostic states listed by Behan-Pelletier (1988). The apparently plicate integument of $J$. foveolatus nymphs also fits Behan-Pelletier's diagnosis, while the lack of adult prodorsal lamellae and humeral projections on the notogaster does not prohibit inclusion. Krivolutsky's familial assignment is, therefore, followed here. 
Genus JUREREMUS Krivolutsky, in Krivolutsky and Krassilov 1977

Type species. Jureremus foveolatus Krivolutsky, in Krivolutsky and Krassilov 1977, from the basin of the Bureya River, Russia; holotype (slide no. 3290/4), paratypes (slide nos 3290/5-15), held in the Paleontological Institute, Moscow.

Emended diagnosis. The following unique combination of character states is proposed: notogaster without a distinct central and marginal area, with an acuminate posterior margin; ventral plate posterior to anus tapering to a narrow point; idiosomal ornamentation foveate; gap between genital and anal apertures equivalent to, at most, onethird of median length of genital aperture.

Remarks. The damage to the holotype of J. phippsi sp. nov. means that many of the character states used in modern generic diagnoses cannot be recorded. The new species is placed in Jureremus because of its similarity to J. foveolatus, the only other member of this genus and also described from material found in Jurassic deposits. Krivolutsky (in Krivolutsky and Krassilov 1977) differentiated Jureremus on the basis of the presence of a transverse, heavily sclerotized ridge between the bothridia, two pairs of longitudinal prodorsal ridges, relatively long dorsal setae, foveate integumental ornamentation and a small posterior idiosomal projection. Jureremus phippsi also has a foveate integument and an acuminate posterior margin, while examination of the types of $J$. foveolatus identified a number of other character states in common. The notogaster has an anterior collar of irregularly ribbed integument (particularly evident in paratype 3290/7) and a band of smooth cuticle at the lateral margins, while the leg cuticle is very weakly foveate. Because there is no evidence that J. phippsi possesses one of the differential features Krivolutsky lists for the genus, i.e. the pattern of transverse and longitudinal prodorsal ridges, the generic diagnosis is emended herein.

Amongst cymbaeremaeid genera [Ametroproctus Higgins and Woolley, 1968, Bullaeremaeus Hammer, 1966, Cymbaeremaeus Berlese, 1896, Glanderemaeus Balogh and Csiszár, 1963, Scapheremaeus Berlese, 1910, Scapuleremaeus Behan-Pelletier, 1989, Seteremaeus Hammer, 1971, and Tectocymba Sellnick, 1919 (fossil)], the body form of Jureremus shows most similarity to Ametroproctus and Cymbaeremaeus. In all three genera, the notogaster has an acuminate posterior margin and the ventral plate narrows to a point behind the anus. Jureremus differs from both in that the genital and anal orifices are farther apart (at least one-quarter of the length of the genital aperture versus almost contiguous), from Ametroproctus by lacking large lamellae and from Cymbaeremaeus by lacking a distinct central and marginal area of the notogaster.

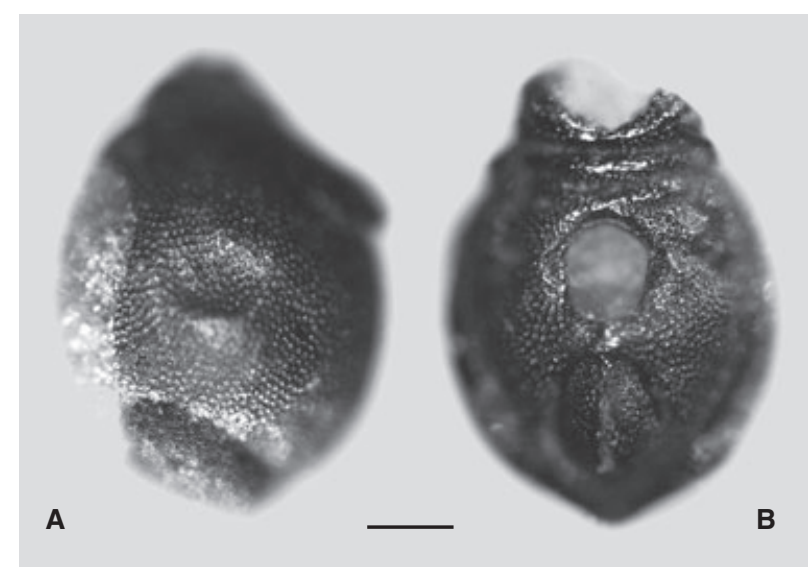

TEXT-FIG. 3. Jureremus phippsi sp. nov, holotype OUMNH J.71472, South Cave, Yorkshire; Oxford Clay Formation. Light microscope photographs before SEM study, showing more complete integument, especially on dorsal side. A, dorsal and B, ventral views. Scale bar represents $100 \mu \mathrm{m}$.

\section{Jureremus phippsi sp. nov. Text-figures 3-5}

Derivation of name. In memory of Arthur Joseph Phipps, father of KJP.

Holotype and only known specimen. OUMNH J.71472 in the Oxford University Museum, from grey mudstone in the Peterborough Member of the Oxford Clay Formation (Jurassic: Upper Callovian: Athleta Zone: Phaeinum Subzone), of South Cave Station Quarry, South Cave, Yorkshire (Text-figs 1-2).

Diagnosis. Can be differentiated from the only other member of the genus (J. foveolatus) by the lack of a transverse ridge between the bothridia and by its smaller size (notogastral length $501 \mu \mathrm{m}$ versus $c$. 600-630 $\mu \mathrm{m}$ ).

Description. Integument well-sclerotized, dark brown, mostly foveate (Text-fig. 3). Prodorsum (Text-fig. 5A-B): lamellae not apparent, although four strips of smooth cuticle just mediolateral to bothridia (b, Text-fig. 5A-B) may indicate presence of prodorsal ridges (?p r, Text-fig. 5A-B); internal architecture of the bothridium (on left of Text-fig. 5B) is evident; sensilli are missing. Notogaster (Text-figs 3A, 4A-B): length $501 \mu \mathrm{m}$, greatest width (measured about mid-length) $390 \mu \mathrm{m}$; irregularly ribbed, weakly foveate collar runs along the anterior margin (c, Text-fig. 4A-B, 5A-D); lateral margins extend ventrally (n, Textfig. $4 \mathrm{C}-\mathrm{D}$ ), posterior margin pointed (Text-fig. 4A-D); pteromorphs absent. Ventral surface of idiosoma (Text-figs 4C-D, 5E-F): pedotecta I and II present (pd, Text-figs 4C-D, 5C-D), the former being the larger; epimera I-III not separated medially (epI-III, Text-fig. 4C-D); IV (epIV) separated, mostly by anterior of genital aperture. Genital aperture (g a, Text-fig. 4C-D) median length $118 \mu \mathrm{m}$, greatest width $97 \mu \mathrm{m}$ (measured at anterolateral angles). Anal aperture large, median length $165 \mu \mathrm{m}$, greatest width c. $127 \mu \mathrm{m}$ (measured just anterior to posterolateral angles). Both anal plates (a pl, Text-figs 4C-D, 5E-F) 


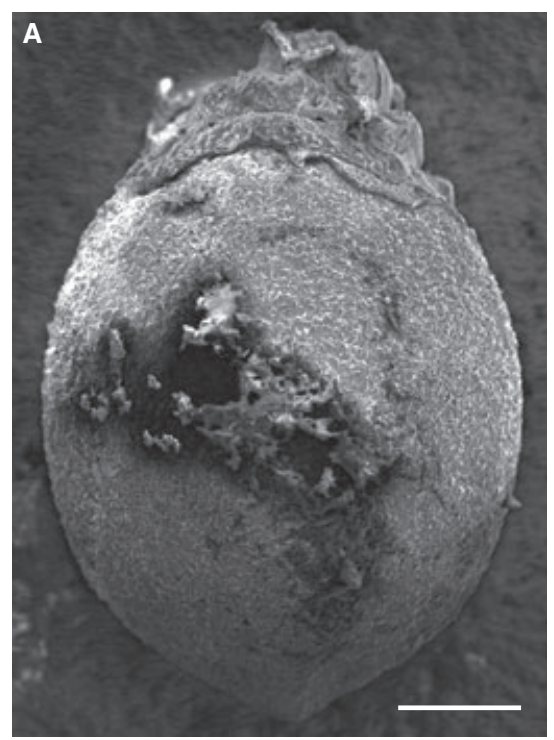

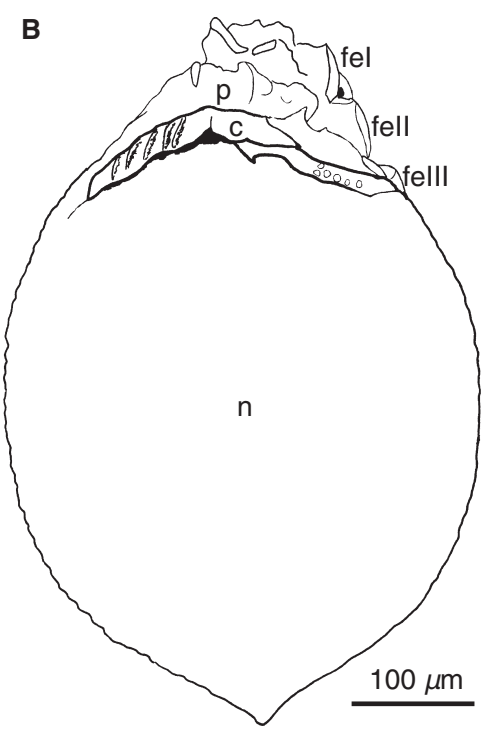

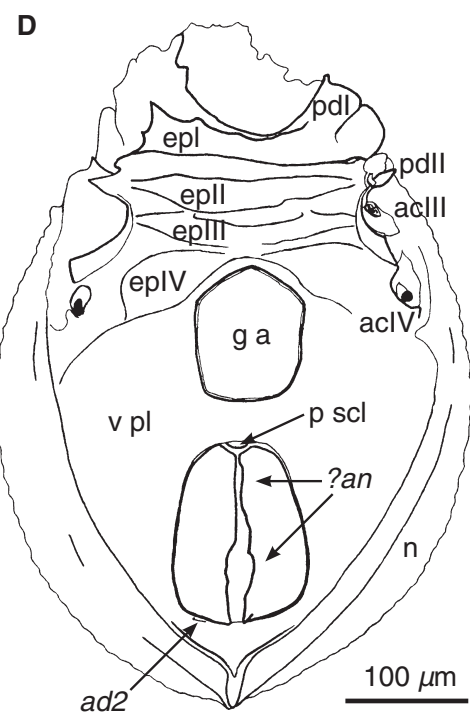

TEXT-FIG. 4. A-D, Jureremus phippsi sp. nov., holotype OUMNH J.71472, South Cave, Yorkshire; Oxford Clay Formation. A-B, SEM photograph of dorsal view of idiosoma and explanatory drawing ( $\mathrm{n}$ marks where notogaster has been lost during preparation for SEM). $\mathrm{C}-\mathrm{D}$, ventral view of idiosoma and explanatory drawing. See text for abbreviations; scale bars represent $100 \mu \mathrm{m}$.

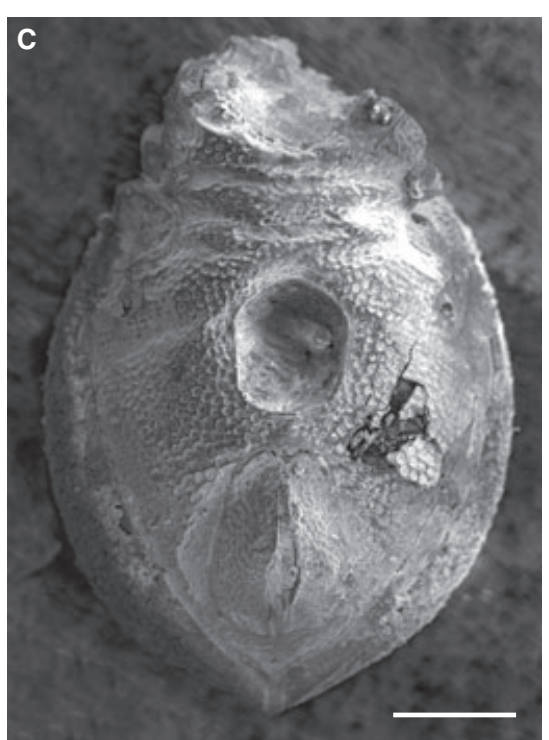

indented anteromedially to accommodate small preanal sclerite (p scl). Possible alveoli of anal setae present on one plate (?an, Text-figs 4C-D, 5E-F). Genital and anal apertures separated by a distance of $30 \mu \mathrm{m}$, equivalent to about one-quarter of median length of genital aperture. Ventral plate ( $\mathrm{v}$ pl, Text-fig. 4C-D) with narrowly pointed posterior margin, bearing serrated seta $(c$. $24 \mu \mathrm{m}$ long) near posterolateral margin of left anal plate: seta identified as adanal seta $a d_{2}$. Acetabula of legs III and IV are evident (ac, Text-fig. 4C-D). Legs (Text-figs 4A-B, 5A-D): trochanter I (trI, Text-fig. 5C-D) and at least part of femora I-III (fe, Text-fig. 5A-D) present. Integument very weakly foveate when observed at high magnification (feI, Text-fig. 5A-B).

\section{DISCUSSION}

The typically soil-dwelling Oribatida is well represented in modern supralittoral and intertidal zones (Schuster 1979), but cymbaeremaeids have not yet been recorded from such habitats. They have mostly been collected from forest niches such as leaf litter, tree canopies and epiphytic plants, although, in addition to Jureremus foveolatus, at least two extant species have been found near freshwater aquatic systems. Scapheremaeus arcuatus Hammer, 1971 was found in wet moss just above the water level of a stream in Fiji (Hammer 1971) and S. petrophagus (Banks, 1906) in cavities in wet rock and lichens adjacent to a waterfall in New York State (Banks 1906; Jacot 1934) and on water-splashed rocks in California (Krantz 1978). Until now, Cymbaeremaeus cymba (Nicolet, 1855) is the only member of the family to have been found in the British Isles (Luxton 1996). Michael recorded it from Epping Forest, Essex, and near Tamworth, Warwickshire (Michael 1879), and from the branches of oak trees in the New Forest, Hampshire (Michael 1888). Hull (1916) 
TEXT-FIG. 5. A-F, Jureremus phippsi sp. nov., holotype OUMNH J.71472, South Cave, Yorkshire; Oxford Clay Formation. A-B, SEM photograph of prodorsum and anterior of notogaster, and explanatory drawing. C-D, anterolateral view of prodorsum and anterior of notogaster, and explanatory drawing. E-F, anal region and explanatory drawing; enlarged details of adanal seta to left (arrowed) and suspected alveolus of anal seta to right (arrowed). See text for abbreviations; scale bars represent $100 \mu \mathrm{m}$.


found it as a result of beating furze (gorse) near Oxford and from an unspecified habitat in Ovingham (Northumberland). It also appears on faunal lists for Cambridgeshire (Warburton 1904; Warburton and Pearce 1904).

Jureremus phippsi is not the first fossil oribatid to be found uncharacteristically in fully marine sediments. The presence of an Early Jurassic specimen of the exclusively freshwater-inhabiting Hydrozetes in Swedish marine sediments was thought to be accidental, the mite possibly having been washed out to sea from a freshwater source (Sivhed and Wallwork 1978). It is possible that the holotype of J. phippsi was similarly carried from a Jurassic river environment before settling on the muddy sediments of the Oxford Clay sea-floor. It could also have been helped on its way by another Jurassic organism. The presence of a fragment of the fern Klukia sp. (KJP collection specimen number SCSQOxCl $\mathrm{mf} 29$ ) in the same sediment sample provides evidence of transportation of organic material from terrestrial sources to the marine environment. It is tempting to suggest that the mite may even have been carried out to sea on this fern pinnule. Fossil woods (e.g. Pearce et al. 2005) and dinosaur remains (Martill et al. 2006) are not uncommon in Jurassic marine clays, so transport into the marine realm on a carcass or driftwood is a possibility.

Atypical occurrences of oribatids can be difficult to explain. The life cycle does not facilitate independent dispersal over long distances; there are no parasitic members and, to date, none is known to have an obligatory phoretic relationship with another organism. Aerial transport evidently does not play an important role over long distances (Pugh 2003), although some aerial dis- 
persal of oribatids has been recorded in forest canopies (Behan-Pelletier and Winchester 1998; Behan-Pelletier and Walter 2000; Karasawa et al. 2005). Coulson et al. (2002) have shown by experiment that mites are able to survive total immersion in sea-water for several weeks, and thus could be transported long distances in ocean currents. There are records of oribatids occurring on birds (Ballard and Ring 1979; Krivolutsky and Lebedeva 2004a, b) and small mammals (Miko and Stanko 1991), while Norton (1980) concluded that high densities of certain taxa on insects, although infrequent occurrences, were evidence of a phoretic relationship. Equivalent Jurassic associations, whether accidental or deliberate, could have contributed to the spread of fossil oribatids to atypical habitats.

Landmasses from which J. phippsi could have originated were located to the north (Mid North Sea High) and the west (Pennine High) of the South Cave region (Bradshaw and Cripps 1992). Although the presence of the Market Weighton Structure may have produced shallow water conditions to the north of South Cave Station Quarry, there is no evidence to indicate the presence of a landmass in that area (Neale 1958).

Acknowledgements. We thank Catherine J. Marriott for preparing the specimen and taking preliminary SEM photographs as part of her undergraduate project. We thank Prof. Alexander Rasnitsyn (Paleontological Institute, Moscow) for the loan of the type material of Jureremus foveolatus, Dr Dmitri Logunov (Manchester) for translating its original description, and Dr Malcolm Luxton (Barry, Wales) and Mr Frank Monson (Liverpool) for contributing their opinions about the higher classification of J. phippsi. Dr Andre V. Bochkov (Russian Academy of Sciences, St Petersburg), Prof. Carlos Flechtmann (USP ESALQ Zoologia, Piracicaba, Brazil), Dr Ekaterina Sidorchuk (Russian Academy of Sciences, Moscow) and Dr Ksenia Semenchenko (Russian Academy of Sciences, Vladivostok) are gratefully acknowledged for providing various information and literature. KJP thanks Mr R. Johnson (North Newbald, Yorkshire) for granting access to South Cave Station Quarry.

\section{REFERENCES}

ARKELL, W. J. 1945. The zones of the Upper Jurassic of Yorkshire. Proceedings of the Yorkshire Geological Society, 25, 339358.

ASH, S. 2000. Evidence of oribatid mite herbivory in the stem of a Late Triassic tree fern from Arizona. Journal of Paleontology, 74, 1065-1071.

BAGNOLI, G., CARNEVAlE, G. and BERNini, F. 2000. Ordovician goes on land. Geological Society of America, Abstracts with Programs, 32 (7), A-14.

BALLARD, J. T. and RING, R. A. 1979. The ectoparasites of some marine birds from Bamfield Marine Station, British Columbia, Canada, with particular reference to the common murre, Uria aalge (Pont.). Canadian Journal of Zoology, 57, 1980-1984.

BALOGH, J. and BALOGH, P. 1998. On the family Micreremidae Grandjean, 1954 (Acari, Oribatei). Opuscula Zoologica Budapest, 31, 17-23.

and CSISZÁR, J. 1963. The zoological results of Gy. Topál's collectings in South Argentina. 5. Oribatei (Acarina). Annales Historico-Naturales Musei Nationalis Hungarici (Zoology), 55, 463-485.

BANKS, N. 1906. A rock-boring mite. Entomological News, 17, 193-194.

BEHAN-PELLETIER, V. M. 1988. Systematic relationships of Ametroproctus, with a modified definition of Cymbaeremaeidae (Acari: Oribatida). 301-307. In CHANNABASAV ANNA, G. P. and VirAKTAMATH, C. A. (eds). Progress in acarology Volume 1. Brill, Leiden, xvi $+523 \mathrm{pp}$.

- 1989. Description of Scapuleremaeus kobauensis gen. nov. sp. nov. (Acari: Oribatida: Cymbaeremaeidae) from western Canada. Canadian Entomologist, 121, 507-513.

and WALTER, D. E. 2000. Biodiversity of oribatid mites (Acari: Oribatida) in tree canopies and litter. 187-202. In COLEMAN, D. C. and HENDRIX, P. F. (eds). Invertebrates as webmasters in ecosystems. CABI, Wallingford, $\mathrm{xi}+336 \mathrm{pp}$.

_ and WINCHESTER, N. 1998. Arboreal oribatid mite diversity: colonizing the canopy. Applied Soil Ecology, 9, 4551.

BERLESE, A. 1896. Acari, Myriopoda et Scorpiones hucusque in Italia reperta. Acari, Myriopoda et Scorpiones hucusque in Italia reperta, Fasc. 79, 15 pp., 6 pls.

1908. Elenco di generi e specie nuove di acari. Redia, 5, 115.

- 1910. Lista di nuove specie e nuovi generi di Acari. Redia, 6, 242-271.

BERNINI, F. 1986. Current ideas on the phylogeny and the adaptive radiations of Acarida. Bolletin de Zoologie, 53, 279-313.

- 1991. Fossil Acarida, 253-262. In SIMONETTA, A. M. and CONWAY MORRIS, S. (eds). The early evolution of Metazoa and the significance of problematic taxa. Cambridge University Press, Cambridge, ix +296 pp.

CARnevale, G., BAGNOLI, G. and StOnge, S. 2002. An Early Ordovician oribatid mite (Acari: Oribatida) from the island of Öland, Sweden. 45-47. In BERNINI, F., NANNELLI, R., NUZZACI, G. and DE LILLO, E. (eds). Acarid phylogeny and evolution. Adaptation in mites and ticks. Kluwer, Dordrecht, $472 \mathrm{pp}$.

BRADSHAW, M. J. and CRIPPS, D. W. 1992. Mid Callovian. 120-123. In COPE, J. C. W., INGHAM, J. K. and RAWSON, P. F. (eds). Atlas of palaeogeography and lithofacies. Geological Society, London, Memoir, 13, $153 \mathrm{pp}$.

BRASIER, M. D. and BRASIER, C. J. 1978. Littoral and fluviatile facies in the 'Kellaways Beds' on the Market Weighton swell. Proceedings of the Yorkshire Geological Society, 42, 1-20.

BRAUN, A. 1997. Vorkommen, Untersuchungsmethoden und Bedeutung tierischer Cuticulae in kohligen Sedimentgesteinen des Devon und Karbons. Palaeontographica A, 245, 83-156.

BULANOVA-ZACHVATKINA, Y. M. 1974. A new genus of mite (Acariformes, Oribatei) from the Upper Cretaceous of Taymyr. Paleontological Journal, 8, 247-250. 
CALLOMON, J. H. 1955. The ammonite succession in the Lower Oxford Clay and Kellaways Beds at Kidlington, Oxfordshire, and the zones of the Callovian Stage. Philosophical Transactions of the Royal Society of London, B, 239, 215-264.

- 1964. Notes on the Callovian and Oxfordian stages. 269291. In MAUBEUGE, P. L. (ed.). Colloque du Jurassique à Luxembourg 1962. Publications de l'Institut Grand-ducal, Section des Sciences Naturelles, Physiques et Mathematiques, Luxembourg, 948 pp.

1968. The Kellaways Beds and the Oxford Clay. 264-290. In SYLVESTER-BRADLEY, P. C. and FORD, T. D. (eds). The geology of the East Midlands. Leicester University Press, Leicester, $400 \mathrm{pp}$.

COETZEE, L. and BRINK, J. S. 2003. Fossil oribatid mites (Acari, Oribatida) from the Florisbad Quaternary deposits, South Africa. Quaternary Research, 59, 246-254.

COULSON, S. J., HODKINSON, I. D., WEBB, N. R. and HARRISON, J. A. 2002. Survival of terrestrial soil-dwelling arthropods on and in seawater: implications for trans-oceanic dispersal. Functional Ecology, 16, 353-356.

COX, B. M. 1988. English Callovian (Middle Jurassic) perisphinctid ammonites. Part 1. Monograph of the Palaeontographical Society, 575, 1-54, pls 1-23.

- HUDSON, J. D. and MARTILL, D. M. 1992. Lithostratigraphic nomenclature of the Oxford Clay (Jurassic). Proceedings of the Geologists' Association, 103, 343-345.

DUFF, K. L. 1978. Bivalvia from the English Lower Oxford Clay (Middle Jurassic). Monograph of the Palaeontographical Society, 553, 1-137. pls 1-13.

DUNLOP, J. A. 2007. A large parasitengonid mite (Acari: Erythraeoidea) from the Early Cretaceous Crato Formation of Brazil. Fossil Record, 10, 91-98.

ELIAS, S. A. 1994. Quaternary insects and their environments. Smithsonian Institution Press, Washington DC, xiii + 284 pp.

ERICKSON, J. M. 1988. Fossil oribatid mites as tools for Quaternary paleoecologists: preservation quality, quantities, and taphonomy. In LAUB, R. S., MILLER, N. G. and STEADMAN, D. W. (eds). Late Pleistocene and early Holocene paleoecology and archaeology of the eastern Great Lakes region. Bulletin of the Buffalo Society of Natural Sciences, 33, 207-226.

- PlATt, R. B. and JENNINGS, D. H. 2003. Holocene fossil oribatid mite biofacies as proxies of paleohabitat at the Hiscock Site, Byron, N.Y. 172-185. In LA UB, R. S. (ed.). The Hiscock Site: later Pleistocene and Holocene paleoecology and archeology of western New York State. Bulletin of the Buffalo Society of Natural Sciences, 37, $\mathrm{x}+327 \mathrm{pp}$.

EWING, H. E. 1937. Arachnida, order Acarina. 56-62. In CARPENTER, F. M., FOLSOM, J. W., ESSIG, E. O., KINSEY, A. C., BRUES, C. T., BOESEL, M. W. and EWING, H. E. (eds). Fossil insects in Canadian amber. University of Toronto Studies, Geological Series, 40, 7-62.

FISHER, I. St J. and HUDSON, J. D. 1987. Pyrite formation in Jurassic shales of contrasting biofacies. 69-78. In BROOKS, J. and FLEET, A. J. (eds). Marine petroleum source rocks. Geological Society, London, Special Publication 26, viii +444 pp.
GRANDJEAN, F. 1954. Essai de classification des Oribates (Acariens). Bulletin de la Société Zoologique de France, 78, 421-446.

GRIMALDI, D. A., ENGEL, M. C. and NASCIMBENE, P. C. 2002. Fossiliferous Cretaceous amber from Myanmar (Burma): its rediscovery, biotic diversity, and paleontological significance. American Museum Novitates, 3361, 1-71.

HAMMEN, L. VAN DER 1968. Introduction générale à la classification, la terminologie morphologique, l'ontogénèse et evolution des acariens. Acarologia, 10, 401-412.

HAMMER, M. 1966. Investigations on the oribatid fauna of New Zealand Part I. Biologiske Skrifter, Kongelige Danske Videnskabernes Selskab, 15 (2), 1-108.

— 1971. On some oribatids from Viti Levu, the Fiji Islands. Biologiske Skrifter, Kongelige Danske Videnskabernes Selskab, 16 (6), 1-60.

HIGGINS, H. G. and WOOLLEY, T. A. 1968. A new mite of the genus Eupterotegaeus from Oregon (Cryptostigmata: Cepheidae). Great Basin Naturalist, 28, 179-182.

HIRST, S. 1923. On some arachnid remains from the Old Red Sandstone (Rhynie Chert bed, Aberdeenshire). Annals and Magazine of Natural History, Series 9, 12, 455-474.

HUDSON, J. D. 1982. Pyrite in ammonite-bearing shales from the Jurassic of England and Germany. Sedimentology, 29, 639667.

— and PALFRAMAN, D. F. B. 1969. The ecology and preservation of the Oxford Clay fauna at Woodham, Buckinghamshire. Quarterly Journal of the Geological Society of London, 124, 387-418.

HULL, J. E. 1916. Terrestrial Acari of the Tyne Province. Transactions of the Natural History Society of Northumberland, Durham and Newcastle-upon-Tyne, New Series, 4, 381423.

JACOT, A. P. 1934. Two species of lichen mining mossmites. Annals of the Entomological Society of America, 27, 462-467.

JERAM, A. J., SELDEN, P. A. and EDWARDS, D. 1990. Land animals in the Silurian: arachnids and myriapods from Shropshire, England. Science, 250, 658-661.

KARASAWA, S., GOTOH, K., SASAKI, T. and HIJII, N. 2005. Wind-based dispersal of oribatid mites (Acari: Oribatida) in a subtropical forest in Japan. Journal of the Acarological Society of Japan, 14, 117-122.

KEEPING, W. and MIDDLEMIS S, C. S. 1883. On some new railway sections and other rock exposures in the district of Cave, Yorkshire. Geological Magazine, 10, 215-22l.

KELLOGG, D. W. and TAYLOR, E. L. 2004. Evidence of oribatid mite detritivory in Antarctica during the late Paleozoic and Mesozoic. Journal of Paleontology, 78, 1146-1153.

KETHLEY, J. B., NORTON, R. A., BONAMO, P. M. and SHEAR, W. A. 1989. A terrestrial alicorhagiid mite (Acari: Acariformes) from the Devonian of New York. Micropaleontology, 35, 367-373.

KLOMPEN, H. and GRIMALDI, D. 2001. First Mesozoic record of a parasitiform mite: a larval argasid tick in Cretaceous amber (Acari: Ixodida: Argasidae). Annals of the Entomological Society of America, 94, 10-15.

KRANTZ, G. W. 1978. A manual of acarology. Second edition. Oregon State University Book Stores, Corvallis, vii +509 pp. 
KRIVOLUTSKY, D. A. and DRUK, A. Y. 1986. Fossil oribatid mites. Annual Review of Entomology, 31, 533-545.

— and KRASSILOV, V. A. 1977. Oribatid mites from Upper Jurassic, USSR. 16-24. In SKARLATO, O. A. and BALASHOV, S. (eds). Morphology and diagnostics of mites. Academy of Sciences of the USSR, Leningrad, $84 \mathrm{pp}$. [In Russian].

- and LEBEDEVA, N. V. 2004a. Oribatid mites (Oribatei, Acariformes) in bird feathers: non-passerines. Acta Zoologica Lituanica, 14 (1), 26-47.

- 2004b. Oribatid mites (Oribatei, Acariformes) in bird feathers: passeriformes. Acta Zoologica Lituanica, 14 (2), 19-38.

- and RYABININ, N. A. 1976. Oribatid mites in Siberian and Far East amber. Reports of the Academy of Sciences, USSR, 230, 945-948. [In Russian].

— and SIDORCHUK, E. A. 2003. Subfossil oribatid mites in the Holocene deposits of the Arkhangel'sk Oblast. Doklady Biological Sciences, 392, 428-431.

—DRUK, A. Y., EITMIMAVIČIŪTĖ, I. S., LASKOVA, L. M. and KARPPINEN, E. 1990. Fossil oribatid mites. Mokslas, Vilnius, 109 pp. [In Russian].

LABANDEIRA, C. C., PHILliPS, T. L. and NORTON, R. A. 1997. Oribatid mites and the decomposition of plant tissues in Paleozoic coal-swamp forests. Palaios, 12, 319-353.

LEACH, W. E. 1817. The zoological miscellany: being descriptions of new or interesting animals. Vol. 3. Nodder and Son, London, vi $+151 \mathrm{pp}$.

LUXTON, M. 1996. Oribatid mites of the British Isles. A checklist and notes on biogeography (Acari, Oribatida). Journal of Natural History, 30, 803-822.

MAcQUAKER, J. H. S. 1994. A lithofacies study of the Peterborough Member, Oxford Clay Formation (Jurassic), UK: an example of sediment bypass in a mudstone succession. Journal of the Geological Society, London, 151, 161-172.

MARTILL, D. M. and HUDSON, J. D. 1991. Fossils of the Oxford Clay. Palaeontological Association, London, Field Guides to Fossils No. 4, 286 pp.

- NAISH, D. and FIELDING, S. 2006. Dinosaurs in marine strata: evidence from the British Jurassic, including a review of the allochthonous vertebrate assemblage from the marine Kimmeridge Clay Formation (Upper Jurassic) of Great Britain. 47-83. In COLECTIVO ARQUEOLÓGICO-PALEONTOLÓGICO SALENSE (ed.). Actas se las III Jornadas Internacionales sobre Paleontología de Dinosaurios y su Entorno. Salas de los Infantes, Burgos (Spain), 385 pp.

TAYLOR, M. A. and DUFF, K. L. 1994. The trophic structure of the biota of the Peterborough Member, Oxford Clay Formation (Jurassic), UK. Journal of the Geological Society, London, 151, 173-194.

McALPINE, J. F. and MARTIN, J. E. H. 1969. Canadian amber - a paleontological treasure-chest. The Canadian Entomologist, 101, 819-838.

MICHAEL, A. D. 1879. A contribution to the knowledge of British Oribatidae. Journal of the Royal Microscopical Society, 2, 225-251.

— 1888. British Oribatidae. Volume 2. Ray Society, London, pp. 337-657.

MIKO, L. and STANKO, M. 1991. Small mammals as carriers of non-parasitic mites (Oribatida, Uropodina). 395-402. In
DUSBABEK, F. and BUKVA, V. (eds). Modern acarology. Volume 1. Academic Publishing, The Hague, vii +649 pp.

NEALE, J. W. 1958. The Jurassic rocks. 159-170. The Market Weighton Upwarp. 170-178. In DE BOER, G., NEALE, J. W. and PENNY, L. F. (eds). A guide to the geology of the area between Market Weighton and the Humber. Proceedings of the Yorkshire Geological Society, 31, 157-209.

NICOLET, H. 1855. Histoire naturelle des Acariens qui se trouvent aux environs de Paris. Archives de Museum d'Histoire Naturelle de Paris, 7, 381-482.

NORTON, R. A. 1980. Observations on phoresy by oribatid mites. International Journal of Acarology, 6, 121-130.

— and POINAR, G. O. 1993. Reassessment and new records of oribatid mite fossils from Tertiary Neotropical amber. Acarologia, 34, 57-68.

- BONAMO, P. M., GRIERSON, J. D. and SHEAR, W. A. 1988. Oribatid mite fossils from a Devonian deposit near Gilboa, New York. Journal of Paleontology, 62, 259-269.

PAGE, K. N. 1989. A stratigraphical revision for the English Lower Callovian. Proceedings of the Geologists' Association, 100, 363-382.

— and COX, B. M. 2002. Drewton Lane Pits. 309-312. In COX, B. M. and SUMBLER, M. G. (eds). British Middle Jurassic Stratigraphy. Geological Conservation Review Series, No. 26. Joint Nature Conservation Committee, Peterborough, 508 pp.

PEARCE, C. R., HESSELBO, S. P. and COE, A. L. 2005. The mid-Oxfordian (Late Jurassic) positive carbon-isotope excursion recognised from fossil wood in the British Isles. Palaeogeography, Palaeoclimatology, Palaeoecology, 221, 343357.

PHIPPS, K. J. 2007. The ammonite succession in the 'Oxford Clay' at South Cave Station Quarry, Yorkshire. Proceedings of the Yorkshire Geological Society, 56, 159-176.

PUGH, P. J. A. 2003. Have mites (Acarina: Arachnida) colonized Antarctica and the islands of the Southern Ocean via air currents? Polar Record, 39, 239-244.

SCHUSTER, R. 1979. Soil mites in the marine environment. 593-602. In RODRIGUEZ, J. G. (ed.). Recent advances in acarology. Volume 1. Academic Press, New York, NY, xxi + $631 \mathrm{pp}$.

SELLNICK, M. 1919. Die Oribatiden der Bernsteinsammlung der Universität Königsberg i. Pr. Schriften der PhysikalischeÖkonomischen Gesellschaft zu Königsberg, 59 (for 1918), 21-42.

- 1928. Formenkreis: Hornmilben, Oribatei. Die Tierwelt Mitteleuropas, 3(9), 1-42.

— 1931. Milben im Bernstein. Bernstein-Forschungen, 2, 148180.

SIVHED, U. and WALLWORK, J. A. 1978. An early Jurassic oribatid mite from southern Sweden. Geologiska Föreningens $i$ Stockholm Förhandlingar, 100, 65-70.

VERCAMMEN-GRANDJEAN, P. H. 1973. Study of the "Erythraeidae R.O.M. No 8" of Ewing, 1937. 329-335. In DANIEL, M. and ROSICKÝ, B. (eds). Proceedings of the 3rd International Congress of Acarology, held in Prague (Czechoslovakia), August 31-September 6, 1971. Academia, Prague, 837 pp. 
WALKER, K. G. 1972. The stratigraphy and bivalve fauna of the Kellaways Beds (Callovian) around South Cave and Newbald, East Yorkshire. Proceedings of the Yorkshire Geological Society, 39, 107-138.

WARBURTON, C. 1904. The Arachnida of Cambridgeshire. 192-203. In MARR, J. E. and SHIPLEY, A. E. (eds). Handbook to the natural history of Cambridgeshire. University Press, Cambridge, vi +260 pp.

and PEARCE, N. D. F. 1904. Exhibition of oribatid mites taken in the neighbourhood of Cambridge. Proceedings of the Cambridge Philosophical Society, 12, 427-429.
WILSON, H. M. and ANDERSON, L. I. 2004. Morphology and taxonomy of Paleozoic millipedes (Diplopoda: Chilognatha: Archipolypoda) from Scotland. Journal of Paleontology, 78, 169-184.

WOOLLEY, T. A. 1971. Fossil oribatid mites from Chiapas, Mexico (Acarina: Oribatei = Cryptostigmata). University of California, Publications in Entomology, 63, 91-99.

ZACHARDA, M. and KRIVOLUTSKY, D. A. 1985. Prostigmatic mites (Acarina: Prostigmata) from the Upper Cretaceous and Paleogene amber of the USSR. Vestník Československé Spolecnosti Zoologické, 49, 147-152. 